\title{
Tick-borne encephalitis vaccination in multiple sclerosis
}

\section{A prospective, multicenter study}

\author{
Alexander Winkelmann, MD, Christoph Metze, Silvius Frimmel, MD, Emil C. Reisinger, MD, MBA, \\ Uwe K. Zettl, MD, and Micha Loebermann, MD \\ Neurol Neuroimmunol Neuroinflamm 2020;7:e664. doi:10.1212/NXI.0000000000000664 \\ e664
}

\section{Abstract}

\section{Objective}

To assess the changes in disease activity after tick-borne encephalitis (TBE) vaccination in patients with multiple sclerosis (MS) on a variety of disease-modifying drugs and to assess the immunogenicity, safety, and clinical tolerability of the vaccine in this patient group.

\section{Methods}

We conducted a prospective, multicenter, nonrandomized observational study. We enrolled 20 patients with MS receiving TBE vaccination who had been on disease-modifying treatment (DMT) for at least 6 months. Serum samples were obtained before and after 4 weeks of vaccination to determine the specific TBE antibody response. MS disease activity (Expanded Disability Status Scale and relapse rates) was evaluated for 1 year after immunization. Local and systemic adverse events were registered.

\section{Results}

In 20 subjects with $\mathrm{TBE}$ vaccination, the annualized relapse rate decreased from 0.65 in the year before vaccination to 0.21 in the following year. Expanded Disability Status Scale remained stable during the 2-year period before vaccination and 1 year after vaccination (range: 1.50-1.97). The geometric mean titer (GMT) increased from 169 Vienna units per milliliter $(\mathrm{VIEU} / \mathrm{mL})$ to $719 \mathrm{VIEU} / \mathrm{mL} 4$ weeks after vaccination $(p=0.001)$, and $77.8 \%$ had protective antibody titers after vaccination. In 9 patients treated with beta interferons, GMT increased from $181 \mathrm{VIEU} / \mathrm{mL}$ to $690 \mathrm{VIEU} / \mathrm{mL}(p=0.018)$. Three subjects treated with glatiramer acetate developed a 2- to 9.6-fold increase. Patients treated with fingolimod developed the lowest increase in antibody titer.

\section{Conclusion}

TBE vaccination showed good tolerability and was safe in patients with MS. MS disease activity was not increased, and annualized relapse rates decreased after vaccination. Vaccine response differs according to the underlying DMT.

\section{Trial registration}

ClinicalTrials.gov, clinicaltrials.gov, Identifier: NCT02275741.

\footnotetext{
From the Department of Neurology (A.W.), University of Rostock, Germany; Section of Neuroimmunology (C.M., U.K.Z.), Department of Neurology; and Department of Tropical Medicine and Infectious Diseases (S.F., E.C.R., M.L.) 


\section{Glossary}

$\mathbf{A E}=$ adverse event; $\mathbf{D M T}=$ disease-modifying treatment; EDSS $=$ Expanded Disability Status Scale; GMT $=$ geometric mean titer; TBE = tick-borne encephalitis; TBEV = TBE flavivirus; VIEU $/ \mathbf{m L}=$ Vienna units per milliliter.

Tick-borne encephalitis (TBE) is an infection of the human CNS caused by the TBE flavivirus (TBEV). It is predominantly transmitted by tick bites and is endemic in Eurasia were $0.1 \%-5 \%$ of ticks harbor TBEV. ${ }^{1}$ The TBE attack rate for travelers to endemic areas in Europe is $0.5-1.3$ per 100,000 for the exposed at-risk population. ${ }^{2}$ Most infected subjects do not develop clinical symptoms. However, up to $25 \%$ of those exposed exhibit CNS involvement-mainly meningitis and meningoencephalitis with a case fatality rate between $0.5 \%$ and $2 \%$ in Europe. ${ }^{3}$ Because of the lack of treatment options available, vaccination and tick-bite prevention are eminent strategies in populations at risk. ${ }^{4}$ Reports of potentially detrimental effects on the course of multiple sclerosis (MS) have prompted both patients and their physicians to adopt a more cautious attitude toward the use of vaccines. Immunocompromised patients may mount a lower immune response and also exhibit a more rapid antibody decline after vaccination. ${ }^{5}$ Special consideration must be given to adequate immune protection against vaccine-preventable diseases before and during immunomodulatory therapy of MS. ${ }^{6}$

The aim of this study was to evaluate the safety and immunogenicity of licensed TBE vaccines in MS.

\section{Methods}

This prospective, multicenter, nonrandomized observational study at specialized outpatient MS care centers included patients with MS aged between 18 and 70 years who had been on disease-modifying treatment (DMT) for at least 6 months and who had an indication for TBE vaccination. Patients with MS relapse or other disease activity during the previous 6 months were excluded.

All patients who received TBE vaccination on a routine basis were offered to participate in this study. Baseline characteristics were collected along with details of the MS disease. Subjects received a single dose of 1 of the 2 available inactivated TBE vaccines (FSME Immun, TBEV Neudoerfl strain; Encepur, TBEV K23 strain) in the deltoid muscle in an openlabel manner.

Serum samples were obtained before and 4 weeks after vaccination. Serology for the TBE immunoglobulin G-antibody response was performed in duplicate using an enzyme immunoassay (FSME immunoglobulin G ELISA; IBL International, Hamburg, Germany) according to the manufacturer's protocol. Titers were expressed in Vienna units per milliliter (VIEU/mL) and rated according to the manufacturer's protocol: $<63 \mathrm{VIEU} / \mathrm{mL}$ negative, $63-126$ $\mathrm{VIEU} / \mathrm{mL}$ borderline, and $>126 \mathrm{VIEU} / \mathrm{mL}$ positive.
Subjects had follow-up visits after 1, 3, 6, and 12 months. Local and systemic adverse events (AEs) were registered after 1 month.

Safety and immunogenicity were analyzed in the intention-totreat population. Samples below the cutoff titer were set to 25 $\mathrm{VIEU} / \mathrm{mL}$ for statistical analysis.

All statistical analyses were performed using Prism 5 (5.04, GraphPad Software Inc.). Values were expressed as mean \pm SD. Mann-Whitney $U$ test was used to compare annualized relapse rates. Where otherwise appropriate, the Wilcoxon rank test was used. All reported $p$ values are 2 sided; values of 0.05 or less were considered to indicate statistical significance.

Table Characteristics of the enrolled subjects

\begin{tabular}{ll}
\hline Group & $\begin{array}{l}\text { Total } \\
\mathbf{N}=\mathbf{2 0}\end{array}$ \\
\hline Age $(\mathbf{y}) \pm$ SD & $41.6 \pm 10.1$ \\
\hline Sex & \\
\hline Men & $3 / 20(15 \%)$ \\
\hline Women & $17 / 20(85 \%)$ \\
\hline Mean duration of disease \pm SD $(\mathbf{y})$ & $6.3 \pm 6.2(\min 0.5 ; \max 19)$ \\
\hline Mean EDSS at vaccination \pm SD & $1.9 \pm 1.4(\min 0 ; \max 5.5)$ \\
\hline MS disease course & \\
\hline RR-MS & $18(90 \%)$ \\
\hline SP-MS & $2(10 \%)$
\end{tabular}

Current DMD at vaccination

\begin{tabular}{ll}
\hline Interferon beta & $10(50 \%)$ \\
\hline Interferon beta 1b & $4(20 \%)$ \\
\hline Interferon beta 1a s.c. & $3(15 \%)$ \\
\hline Interferon beta 1a i.m. & $3(15 \%)$ \\
\hline Glatiramer acetate & $5(25 \%)$ \\
\hline Fingolimod & $2(10 \%)$ \\
\hline Natalizumab & $1(5 \%)$ \\
\hline Cyclic GCS pulse & $1(5 \%)$ \\
\hline No treatment & $1(5 \%)$ \\
\hline Previous use of DMD & $9 / 19(47.4 \%)$ \\
\hline
\end{tabular}

Abbreviations: $\mathrm{DMD}=$ disease modifying drug; $\mathrm{EDSS}=$ Extended Disability Status Scale; GCS = glucocorticosteroids; RR-MS = relapsing-remitting MS; SP-MS = secondary progressive MS 
Standard protocol approvals, registrations, and patient consents

The study was approved by the local ethics committee (Rostock HV 2010-0002) and registered at ClinicalTrials.gov (NCT02275741). The study was conducted in accordance with the International Conference on Harmonization Guidelines for Good Clinical Practice and the Declaration of Helsinki.

\section{Data availability}

Anonymized data on individual patient level will be shared by request from any qualified investigator.

\section{Results}

In total, 20 patients with MS aged between 25 and 65 years received the TBE vaccine and were included in this study (table).

The annualized relapse rate was 0.5 two years before vaccination and 0.65 in the year before vaccination. After vaccination, 3 relapses occurred: (1) 62 days after vaccination, (2) between month 4 and 6 , and (3) between month 7 and 12, resulting in a reduction of the annualized relapse rate to $0.2143(p=0.0459)$ (figure 1A). Mean Expanded Disability Status Scale (EDSS) remained stable during the 2-year period before vaccination and 1-year period after vaccination. The mean EDSS at vaccination was 1.88 , and there was a nonsignificant decrease in (1.62 and 1.50) 3 and 6 months after vaccination (figure 1B).

Four of 20 subjects reported local side effects (pain, induration); none reported systemic AEs during the 4 weeks after vaccination. No additional autoimmune disease was registered during the 1-year of follow-up.

Prevaccination and postvaccination serum samples were available for 18 of 20 subjects. Four of these subjects received a covaccination against tetanus/diphtheria and 2 others received a covaccination against seasonal influenza at the time of TBE vaccination.

Geometric mean titers (GMTs) in these 18 patients increased from 169 to $719 \mathrm{VIEU} / \mathrm{mL} 4$ weeks after vaccination $(p=0.001)$, and $14 / 18(77.8 \%)$ developed protective antibody titers.

Among the subjects without detectable antibody titers before vaccination (4/18 subjects), only 1 developed detectable, though not protective, antibody titers. In those 14 subjects with detectable antibody titers before vaccination, GMT increased from 732 to $3,416 \mathrm{VIEU} / \mathrm{mL}(p=0.001)$ (figure 2). Among 9 patients treated with beta interferons, GMT increased from $181 \mathrm{VIEU} / \mathrm{mL}$ to $690 \mathrm{VIEU} / \mathrm{mL}(p=0.018)$.

Figure 1 Annualized relapse rates (A) and mean EDSS (B)
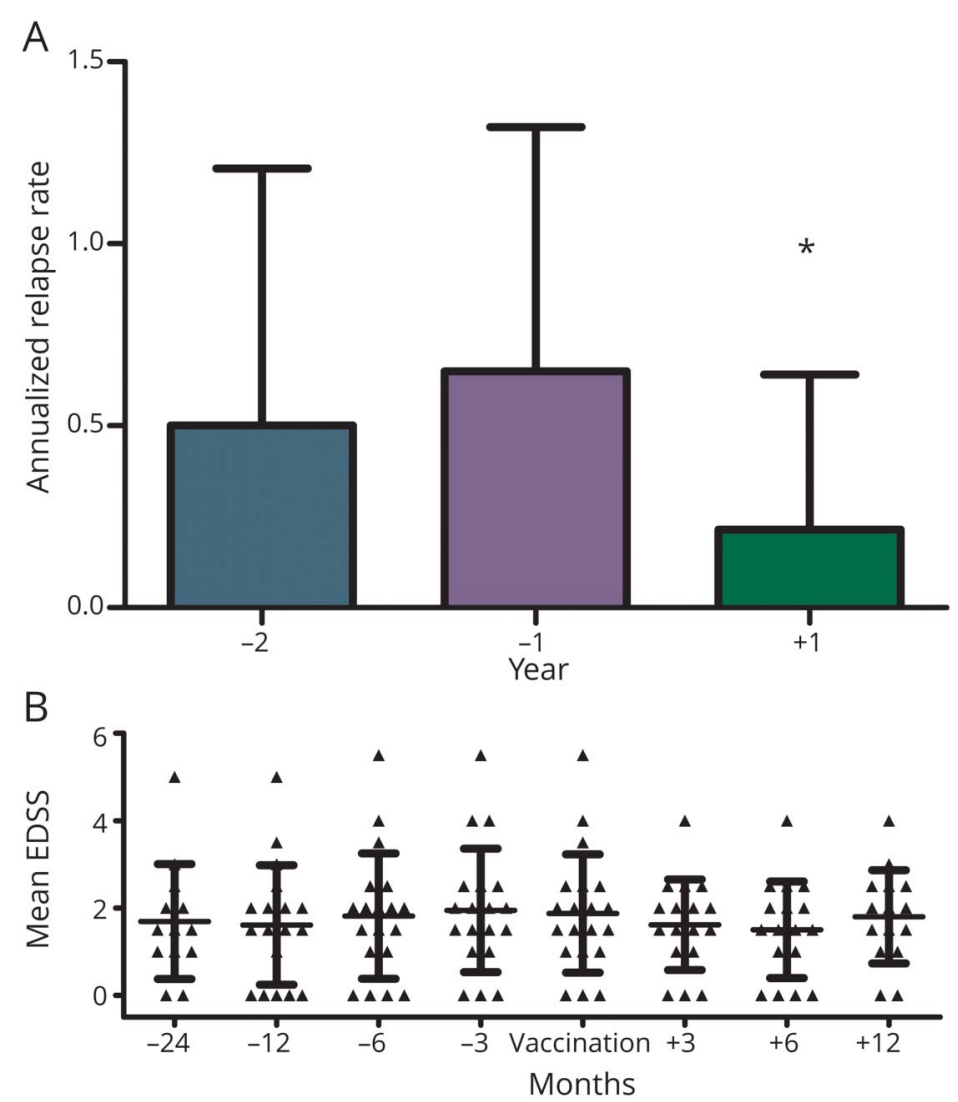

${ }^{*} p=0.0459$ (year -1 vs year +1$)$. (A) Annualized relapse rates during the 2-year period before and 1-year period after TBE vaccination. (B) Mean EDSS during the 2-year period before and the 1-year period after TBE vaccination. EDSS = Extended Disability Status Scale; TBE = tick-borne encephalitis. 
Figure 2 TBE antibody titers

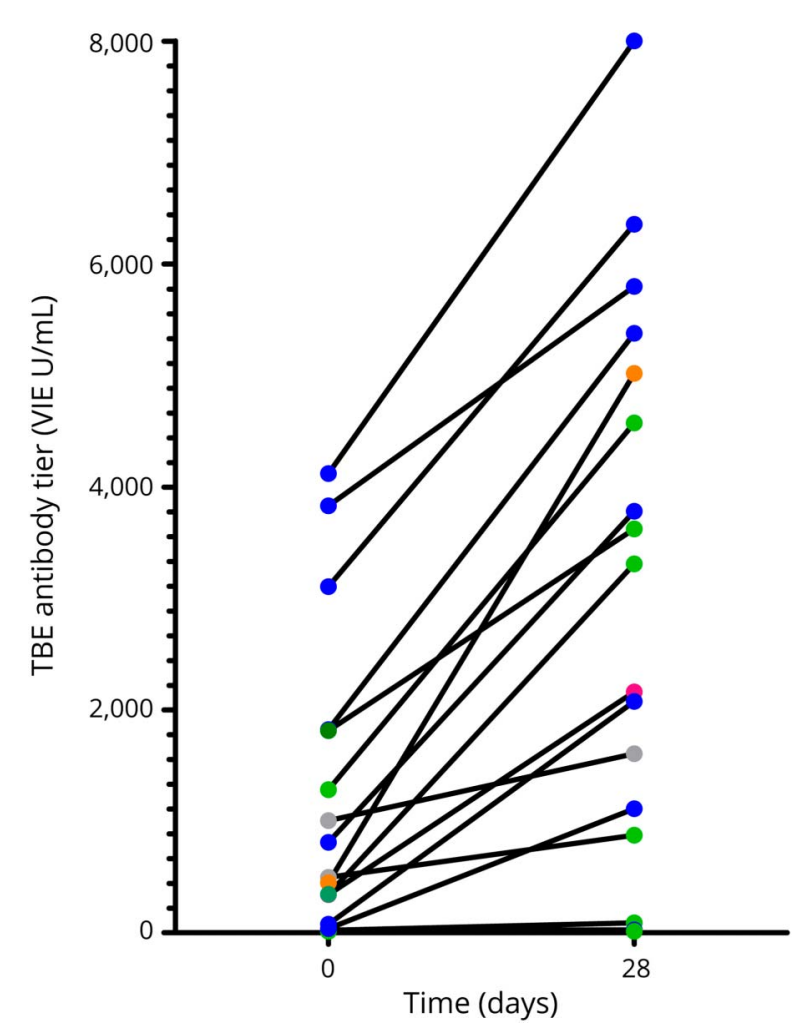

TBE titers before and after 28 days vaccination. Subjects are grouped according to underlying MS therapy (color coding: interferon beta: blue, glatiramer acetate: green, fingolimod: gray, natalizumab: red, cyclic glucocorticosteroids [GCS] pulse: orange). TBE = tick-borne encephalitis; VIEU $/ \mathrm{mL}$ = Vienna units per milliliter.

Two patients treated with interferon beta-1a i.m. for 6 months (38-year-old man, EDSS 1.0) and 112 months (46-year-old woman, EDSS 2.0) showed no antibody response. Another patient treated with interferon beta-1a i.m. developed a 2 -fold antibody titer increase after TBE vaccination.

Three of 5 subjects treated with glatiramer acetate had protective titers before vaccination and developed a 2-, 3.6-, and 9.6-fold increase, respectively. Two other patients with glatiramer acetate treatment developed insignificant antibody titers and both were vaccinated with TBE and another vaccination (influenza or tetanus/diphtheria).

Two patients treated with fingolimod developed the lowest antibody increase compared with other treatment groups (1.76- and 1.59-fold, respectively).

\section{Discussion}

The use of TBE vaccination may be influenced by concerns of vaccination-associated induction or deterioration of MS. Data on patients with MS in the context of TBE vaccination are scarce. One randomized controlled trial showed no increase in MRI activity in 15 patients with MS 6 weeks after TBE vaccination. ${ }^{7}$ In our cohort, no altered clinical disease activity was detected after vaccination. Annualized relapse rates decreased and relapses were rare. The first relapse occurred 62 days after vaccination, making a relationship to the vaccine unlikely.

The long-held concerns that some vaccines might induce autoimmune diseases or lead to an aggravation of existing autoimmune diseases such as MS are unfounded. ${ }^{8,9}$ In our cohort, neither neurologic complications nor autoimmune diseases nor other systemic AEs were reported during the follow-up. Although reporting or recall biases cannot be excluded, overall AEs were low. In healthy vaccinees, seroconversion after vaccination is reported in $92 \%-100 \%{ }^{4}$ All subjects with protective antibody titers mounted an adequate immune response irrespective of the underlying DMT are studied.

The 2 subjects on fingolimod treatment had a low TBE antibody increase as compared to subjects treated with other DMT. However, because of the small number of patients, conclusions regarding responses in patients on individual DMT must be viewed cautiously.

A comparably low antibody response in fingolimod treatment was described after influenza vaccination. ${ }^{10}$ In 6 of 18 subjects, TBE was given simultaneously with other vaccines (influenza, tetanus/diphtheria). Notably, 3 of 4 subjects who did not respond to the TBE vaccine received a covaccination. However, interference between vaccines given simultaneously has not yet been adequately evaluated.

Overall, patients developed a 4.26-fold GMT increase. However, 4 subjects did not respond to TBE vaccination. TBE antibody response monitoring might be advisable in patients with DMT. A drawback of this study is its small sample size without randomization. A correlation between clinical disease activity and MRI may have been desirable; however, this study was performed under routine clinical care and routine cerebral imaging is not the standard of care in asymptomatic patients. In addition, the intrascanner and interscanner variability of MRI would have likely led to inconsistent results in this multicenter setting. We therefore focused on clinical findings. Moreover, neither classic immunosuppressive treatments, nor dimethyl fumarate or teriflunomide, nor recently licensed monoclonal antibody therapies (e.g., ocrelizumab or alemtuzumab) against MS were represented in our cohort. However, real-world clinical data on MS activity for relatively long periods of prevaccination and postvaccination were taken into account. In conclusion, this pilot study and available literature make it likely that TBE vaccine is safe in patients with MS. However, MS treatment with recently licensed drugs, not covered in this study, need further investigation.

\section{Acknowledgment}

The authors would like to thank Ina Schröder for her continuous help with all aspects of this study and her expertise in patient care, and Nicole Deinet and Kati Russow for 
performing accountability and serology. The authors thank our colleagues from NeuroTransData (NTD) for contributing patients.

\section{Study funding}

No targeted funding.

\section{Disclosure}

A. Winkelmann reports personal compensation from Bayer Healthcare, Celgene, Merck, Novartis, Sanofi Genzyme, and Teva. C. Metze reports no disclosures. S. Frimmel reports research support from Pfizer. E.C. Reisinger reports research support from Cempra, Gilead, GSK, Janssen, Novartis Vaccines, Pfizer, Schering, Seqirus, Themis Bioscience, Valneva and Vectura. U.K. Zettl received speaking fees and travel support for research activities from Alexion, Almirall, Bayer, Biogen, Merck Serono, Novartis, Roche, Sanofi Genzyme, Teva as well as EU, BMBF, BMWi, and DFG. M. Loebermann reports personal compensation from Gilead, Janssen, Pfizer and Sanofi and research support from Cempra, Correvio, Pfizer, Sanofi, Schering, Seqirus, Themis Bioscience, Valneva and Vectura. Go to Neurology.org/NN for full disclosures.

\section{Publication history}

Received by Neurology: Neuroimmunology \& Neuroinflammation August 28, 2019. Accepted in final form November 26, 2019.

\section{Appendix Authors}

\begin{tabular}{|c|c|c|c|}
\hline Name & Location & Role & Contribution \\
\hline $\begin{array}{l}\text { Alexander } \\
\text { Winkelmann, } \\
\text { MD }\end{array}$ & $\begin{array}{l}\text { University of } \\
\text { Rostock, Germany, } \\
\text { Department of } \\
\text { Neurology }\end{array}$ & Author & $\begin{array}{l}\text { Design and } \\
\text { conceptualized } \\
\text { study; major role in } \\
\text { the acquisition of } \\
\text { data; analyzed and } \\
\text { interpreted the data; } \\
\text { drafted the } \\
\text { manuscript, and } \\
\text { revised the } \\
\text { manuscript for } \\
\text { intellectual content }\end{array}$ \\
\hline $\begin{array}{l}\text { Christoph } \\
\text { Metze }\end{array}$ & $\begin{array}{l}\text { University of } \\
\text { Rostock, Germany, } \\
\text { Section of } \\
\text { Neuroimmunology, } \\
\text { Department of } \\
\text { Neurology and } \\
\text { Klinikum Ernst von } \\
\text { Bergmann, } \\
\text { Department of } \\
\text { Neurology, Potsdam, } \\
\text { Germany }\end{array}$ & Author & $\begin{array}{l}\text { Major role in the } \\
\text { acquisition of data; } \\
\text { revised the } \\
\text { manuscript for } \\
\text { intellectual content }\end{array}$ \\
\hline
\end{tabular}

Appendix (continued)

\begin{tabular}{|c|c|c|c|}
\hline Name & Location & Role & Contribution \\
\hline $\begin{array}{l}\text { Silvius } \\
\text { Frimmel, MD }\end{array}$ & $\begin{array}{l}\text { University of } \\
\text { Rostock, Germany, } \\
\text { Department of } \\
\text { Tropical Medicine } \\
\text { and Infectious } \\
\text { Diseases }\end{array}$ & Author & $\begin{array}{l}\text { Interpreted the data; } \\
\text { revised the } \\
\text { manuscript for } \\
\text { intellectual content }\end{array}$ \\
\hline $\begin{array}{l}\text { Emil C. } \\
\text { Reisinger, } \\
\text { MD, MBA }\end{array}$ & $\begin{array}{l}\text { University of } \\
\text { Rostock, Germany, } \\
\text { Department of } \\
\text { Tropical Medicine } \\
\text { and Infectious } \\
\text { Diseases }\end{array}$ & Author & $\begin{array}{l}\text { Interpreted the data; } \\
\text { revised the } \\
\text { manuscript for } \\
\text { intellectual content }\end{array}$ \\
\hline $\begin{array}{l}\text { Uwe K. Zettl, } \\
\text { MD }\end{array}$ & $\begin{array}{l}\text { University of } \\
\text { Rostock, Germany, } \\
\text { Section of } \\
\text { Neuroimmunology, } \\
\text { Department of } \\
\text { Neurology }\end{array}$ & Author & $\begin{array}{l}\text { Design and } \\
\text { conceptualized } \\
\text { study; interpreted } \\
\text { the data; revised the } \\
\text { manuscript for } \\
\text { intellectual content }\end{array}$ \\
\hline $\begin{array}{l}\text { Micha } \\
\text { Loebermann, } \\
\text { MD }\end{array}$ & $\begin{array}{l}\text { University of } \\
\text { Rostock, Germany, } \\
\text { Department of } \\
\text { Tropical Medicine } \\
\text { and Infectious } \\
\text { Diseases }\end{array}$ & Author & $\begin{array}{l}\text { Design and } \\
\text { conceptualized } \\
\text { study; analyzed and } \\
\text { interpreted the data; } \\
\text { drafted the } \\
\text { manuscript, and } \\
\text { revised the } \\
\text { manuscript for } \\
\text { intellectual content }\end{array}$ \\
\hline
\end{tabular}

\section{References}

1. Riccardi N, Antonello RM, Luzzati R, Zajkowska J, Di Bella S, Giacobbe DR. Tickborne encephalitis in Europe: a brief update on epidemiology, diagnosis, prevention, and treatment. Eur J Intern Med 2019;62:1-6.

2. Steffen R. Epidemiology of tick-borne encephalitis (TBE) in international travellers to Western/Central Europe and conclusions on vaccination recommendations. J Travel Med 2016;23:taw018.

3. Bogovic P, Lusa L, Korva M, et al. Inflammatory immune responses in the pathogenesis of tick-borne encephalitis. J Clin Med 2019;8:E731.

4. WHO. Vaccines against tick-borne encephalitis: WHO position paperrecommendations. Vaccine 2011;29:8769-8770.

5. Eckerle I, Rosenberger KD, Zwahlen M, Junghanss T. Serologic vaccination response after solid organ transplantation: a systematic review. PLoS One 2013;8: e56974.

6. Zrzavy T, Kollaritsch H, Rommer PS, et al. Vaccination in multiple sclerosis: friend or foe? Front Immunol 2019;10:1883.

7. Baumhackl U, Franta C, Retzl J, Salomonowitz E, Eder G. A controlled trial of tickborne encephalitis vaccination in patients with multiple sclerosis. Vaccine 2003; 21(suppl 1):S56-S61.

8. Loebermann M, Winkelmann A, Hartung HP, Hengel H, Reisinger EC, Zettl UK. Vaccination against infection in patients with multiple sclerosis. Nat Rev Neurol 2012; $8: 143-151$.

9. Hapfelmeier A, Gasperi C, Donnachie E, Hemmer B. A large case-control study on vaccination as risk factor for multiple sclerosis. Neurology 2019;93: e908-e916.

10. Metze C, Winkelmann A, Loebermann M, et al. Immunogenicity and predictors of response to a single dose trivalent seasonal influenza vaccine in multiple sclerosis patients receiving disease-modifying therapies. CNS Neurosci Ther 2019;25: 245-254. 


\section{Neurology \\ Neuroimmunology \& Neuroinflammation}

\section{Tick-borne encephalitis vaccination in multiple sclerosis: A prospective, multicenter study}

Alexander Winkelmann, Christoph Metze, Silvius Frimmel, et al.

Neurol Neuroimmunol Neuroinflamm 2020;7;

DOI 10.1212/NXI.0000000000000664

This information is current as of January 9, 2020

Updated Information \&

Services

References

Subspecialty Collections

Permissions \& Licensing

Reprints including high resolution figures, can be found at:

http://nn.neurology.org/content/7/2/e664.full.html

This article cites 10 articles, 0 of which you can access for free at: http://nn.neurology.org/content/7/2/e664.full.html\#\#ref-list-1

This article, along with others on similar topics, appears in the following collection(s):

All Clinical trials

http://nn.neurology.org//cgi/collection/all_clinical_trials

Multiple sclerosis

http://nn.neurology.org//cgi/collection/multiple_sclerosis

Viral infections

http://nn.neurology.org//cgi/collection/viral_infections

Information about reproducing this article in parts (figures,tables) or in its entirety can be found online at:

http://nn.neurology.org/misc/about.xhtml\#permissions

Information about ordering reprints can be found online:

http://nn.neurology.org/misc/addir.xhtml\#reprintsus

Neurol Neuroimmunol Neuroinflamm is an official journal of the American Academy of Neurology.

Published since April 2014, it is an open-access, online-only, continuous publication journal. Copyright

Copyright $\odot 2020$ The Author(s). Published by Wolters Kluwer Health, Inc. on behalf of the American

Academy of Neurology.. All rights reserved. Online ISSN: 2332-7812.

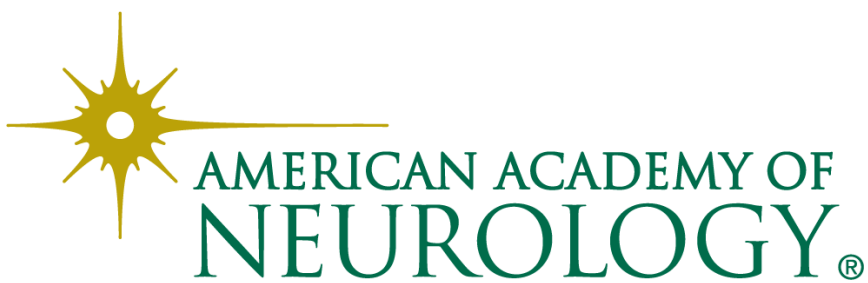

